University of Nebraska - Lincoln

DigitalCommons@University of Nebraska - Lincoln

Faculty Publications: Department of

Entomology

Entomology, Department of

2009

\title{
Lyophilization of Spodoptera frugiperda (Lepidoptera: Noctuidae) larvae yields high-quality DNA for use in AFLP genetic studies
}

\author{
Pete L. Clark \\ University of Nebraska-Lincoln \\ David J. Isenhour \\ Monsanto Company \\ Steven R. Skoda \\ USDA-ARS-SPASRU \\ Jaime Molina-Ochoa \\ University of Nebraska-Lincoln, jmolina18@hotmail.com \\ Claudia Gianni \\ Monsanto Company
}

See next page for additional authors

Follow this and additional works at: https://digitalcommons.unl.edu/entomologyfacpub

Part of the Entomology Commons

Clark, Pete L.; Isenhour, David J.; Skoda, Steven R.; Molina-Ochoa, Jaime; Gianni, Claudia; and Foster, John E., "Lyophilization of Spodoptera frugiperda (Lepidoptera: Noctuidae) larvae yields high-quality DNA for use in AFLP genetic studies" (2009). Faculty Publications: Department of Entomology. 165.

https://digitalcommons.unl.edu/entomologyfacpub/165

This Article is brought to you for free and open access by the Entomology, Department of at DigitalCommons@University of Nebraska - Lincoln. It has been accepted for inclusion in Faculty Publications: Department of Entomology by an authorized administrator of DigitalCommons@University of Nebraska - Lincoln. 


\section{Authors}

Pete L. Clark, David J. Isenhour, Steven R. Skoda, Jaime Molina-Ochoa, Claudia Gianni, and John E. Foster 


\title{
Lyophilization of Spodoptera frugiperda (Lepidoptera: Noctuidae) larvae yields high-quality DNA for use in AFLP genetic studies
}

\author{
Pete L. Clark ${ }^{1,2}$, David J. Isenhour ${ }^{1}$, Steven R. Skoda ${ }^{3}$, \\ Jaime Molina-Ochoa ${ }^{2,4 *}$, Claudia Gianni ${ }^{1}$ \\ and John E. Foster ${ }^{2}$ \\ ${ }^{1}$ Monsanto Company, 800 North Lindbergh Boulevard, \\ St Louis, Missouri 63167, USA: ${ }^{2}$ Department of Entomology, \\ University of Nebraska-Lincoln, Lincoln, Nebraska 68583-0816, USA: \\ ${ }^{3}$ USDA-ARS-SPASRU Screwworm Research Unit, Panama City, \\ Republic of Panamá: ${ }^{4}$ Facultad de Ciencias Biológicas y Agropecuarias, \\ Universidad de Colima, Km. 40, autopista Colima-Manzanillo, \\ Apartado Postal No. 36, Tecomán, \\ Colima 28930, México
}

(Accepted 11 May 2009)

\begin{abstract}
Agricultural research in the 21st century has become a collaborative effort. Research on crop pests like Spodoptera frugiperda (J.E. Smith), commonly known as the fall armyworm (FAW), can involve international collaboration because it is a pest not only in the southern United States, but also in Latin and South America. Our interest to study the genetic variation of 24 subpopulations of FAW from the southern United States, Mexico, Puerto Rico, Brazil and Argentina required insect collection procedures that preserve the integrity of DNA for molecular genetic analysis. The samples were collected primarily from maize (Zea mays L.), but also included outliers collected from pigweed (Amaranthus sp.), Royal Paulownia (Paulownia tomentosa (Thunb.) Sieb. and Zucc. ex Steud.), lemon tree (Citrus limon (L.) Burm) and Bermuda grass (Cynodon dactylon (L.) Pers.). A common insect preservation technique is to place individual insects in 95\% ethanol (ETOH). However, various regulations for shipping and the size of this insect often prevent large sample sizes stored in ETOH from being imported. Genomic DNA from samples preserved in 95\% ETOH, lyophilized and fresh insects was extracted and evaluated using DNA quantification and polymerase chain reaction-amplified fragment length polymorphism (PCR-AFLP). All three treatments yielded high-quality/high molecular weight (c. $70-$ $150 \mu \mathrm{g})$ DNA. No differences in quality of genomic DNA for AFLP analysis were observed. Lyophilization is a reliable tool to preserve FAW samples, which yields highquality DNA for use in AFLP genetic analysis.
\end{abstract}

Key words: lyophilization, fall armyworm, AFLP, PCR, DNA, Spodoptera frugiperda

*E-mail: jmolina@ucol.mx; jmolina18@hotmail.com 


\section{Introduction}

Molecular marker systems to study the genetics of insects are now common in entomological research. The most critical component of molecular genetic studies is high-quality DNA (Saha et al., 1997; Kang and Yang, 2004). Accepted methods of preserving samples for later extraction of DNA are storage in high-percentage ethanol $(\mathrm{ETOH}$; $70-95 \%)$, acetone and freezing $\left(-20\right.$ to $\left.-80^{\circ} \mathrm{C}\right)$. Lyophilization is a common practice for preserving plant and bacterial tissue for molecular analysis. However, there is a lack of data on the use of lyophilization to preserve insect samples for molecular genetic analysis.

The insect used for this study to test viability of DNA after lyophilization was fall armyworm (FAW) Spodoptera frugiperda (J.E. Smith) (Lepidoptera: Noctuidae). A major challenge of studying a pest that is of international importance is the acquisition of specimens. Importation of FAW larvae into the United States from South American countries is achievable according to United States Department of Agriculture, Animal and Plant Health Inspection Service using a Plant Protection and Quarantine 526 arthropod pest permit. However, removing FAW from South American countries is another matter. Many countries such as Brazil and Mexico have restrictions on removal of organisms from their countries. Arrangements can be made by obtaining the proper permit for removal in ETOH. Since the terrorist attack on the United States on 11 September 2001, international airlines and various United States governmental agencies have become wary of flammables brought into the United States. Carrying samples in $95 \% \mathrm{ETOH}$, while possible, is no longer feasible because of the amount of bureaucracy that one must go through to obtain the shipping permission. Hence other useable techniques for shipment should be developed.

Fukatsu (1999) evaluated the use of acetone as a convenient and reliable method for preserving DNA for molecular analysis. The results showed that insects preserved in acetone had viable DNA and could be stored at room temperature for several years. Using acetone for our research became unfeasible due to the nature of our collections: (1) FAW for this research project were collected in the field in the summer months; and (2) the volatile nature of acetone as well as the regulations for transit of the samples in microcentrifuge tubes made this method an impossibility.

Such challenges for importing samples necessitated that we develop other means for importing samples from Latin and South America. Lyophilization has been used to preserve and analyse plant and bacterial tissues and cells on a molecular level. The literature on lyophilization is sparse; however, Saha et al. (1997) addressed whether or not lyophilization is a viable method for preserving DNA for molecular research. Their study compared the use of lyophilized and nonlyophilized cotton leaf and root tissues as sources for isolation of DNA, RNA and protein. Their results showed that: (1) freeze-dried leaf tissue from either greenhouse or field-grown cotton yielded high molecular weight genomic DNA; and (2) DNA extracted was suitable for restriction enzyme digestion and a template for polymerase chain reaction (PCR) amplification. In contrast, lyophilization led to the degradation of RNA in leaf and root tissues. Total proteins of leaves and roots were unaffected by lyophilization based on comparison of polypeptide profiles by denaturing polyacrylamide electrophoresis.

Amplified fragment length polymorphism (AFLP) was used as a molecular tool to evaluate the quality of the DNA from lyophilized FAW tissue. The AFLP technique is based on selective PCR amplification of restriction fragments from genomic DNA. PCR amplification of restriction fragments is done using adapted and restriction site sequences as target sites for primer annealing. Selective amplification is accomplished by amplifying fragments when the primer extensions match the nucleotides flanking the restriction site. PCR-AFLP allows for the use of restriction fragment sets to be visualized by PCR without knowledge of the nucleotide sequence. McMichael and Prowell (1999) used 10 AFLP markers to compare the rice and maize host strains of FAW. The AFLP data identified two distinct populations that the majority of individuals could be associated with. However, not all individuals could be associated with a specific host strain. They found that some individuals on a single host can contain allozyme genotype characteristics of one host strain and a mitochondrial genotype of the other host strain. Busato et al. (2004) also used AFLP to distinguish between different populations of FAW in Brazil, and revealed that AFLP is a useful tool in distinguishing population differences between FAW. A drawback of ALFP is that the procedure may require large amounts of $\mathrm{DNA}$ and the process requires multiple operations (Hoy, 2003). The objective for this study was to determine the reliability of the lyophilization of FAW larvae to yield high-quality DNA for use in AFLP genetic analysis.

\section{Materials and methods}

FAW larvae were either fresh, preserved in 95\% ETOH or lyophilized (immediately after collection). 
The larval samples for the study were: seven lyophilized FAW samples from Argentina, seven fresh larvae collected from late-planted maize in Iowa (USA) and seven FAW larvae preserved in 95\% ETOH from Mexico.

Lyophilization was done immediately after field specimen collection. As larvae were collected in the field, they were placed in $1.5 \mathrm{ml}$ microcentrifuge tubes. A $1 \mathrm{~mm}$ hole was made in the top of each microcentrifuge tube to allow for pressure equalization in the lyophilizer. A Freeze Dry Company
$1 \times$ Tris-Cl/EDTA (TE) buffer until the fluorescence of the bands was equal to $22.2 \mathrm{ng} / \mu \mathrm{l}$ of genomic DNA. PCR-AFLP was used to evaluate the integrity of the DNA from lyophilized samples for molecular genetic analysis. A modification of the PCR-AFLP (Table 1) protocol (Vos et al., 1995) was used for DNA fingerprinting of the samples. A PTC-200 Peltier Thermo Cycler (MJ Research, Waltham, Massachusetts, USA) was used to complete all PCR. Three selective primer combinations were used to selectively amplify

Table 1. Steps used for amplified fragment length polymorphism (AFLP) analysis of fall armyworm larval DNA samples

\begin{tabular}{|c|c|c|}
\hline AFLP step & DNA type & Reagents \\
\hline Restriction digestion & Genomic $(7 \mu \mathrm{l})$ & $\begin{array}{l}\text { One-Phor-All buffer; EcoRI and MseI enzyme; BSA; } \\
\text { deionized } \mathrm{H}_{2} \mathrm{O}\end{array}$ \\
\hline Adapter ligation & & $\begin{array}{l}\text { EcoRI and MseI adapters; T4 DNA ligase with buffer; } \\
\text { deionized } \mathrm{H}_{2} \mathrm{O}\end{array}$ \\
\hline Preamplification & & $\begin{array}{l}\text { Preamp Primer Mix II; } 10 \times \text { PCR buffer; } 15 \mathrm{mM} \mathrm{MgCl}_{2} \text {; } \\
\text { Amplitaq DNA polymerase }\end{array}$ \\
\hline Selective amplification & Preamplification $(2 \mu l)$ product & $\begin{array}{l}10 \times \text { PCR buffer; } 15 \mathrm{mM} \mathrm{MgCl}_{2} \text {; Amplitaq DNA polymerase; } \\
\text { EcoRI-labelled primer; MseI-unlabelled primer }\end{array}$ \\
\hline
\end{tabular}

Table 2. Primers used for amplified fragment length polymorphism analysis of preserved genomic DNA of fall armyworm larvae

\begin{tabular}{lll}
\hline Primer & Primer type & Sequence $\left(5^{\prime}-3^{\prime}\right)$ \\
\hline $\mathrm{E}(\mathrm{N}+0+3)$ & Eco RI-labelled 700 IR (LI-COR, Lincoln, Nebraska, USA) & GAC TGC GTA CCA ATT C ACT \\
$\mathrm{M}(\mathrm{N}+1+2)$ & MseI unlabelled (Invitrogen, Carlsbad, California, USA) & GAT GAG TCC TGA GTA A CAC \\
$\mathrm{M}(\mathrm{N}+1+2)$ & MseI unlabelled (Invitrogen) & GAT GAG TCC TGA GTA A CAG \\
$\mathrm{M}(\mathrm{N}+1+2)$ & MseI unlabelled (Invitrogen) & GAT GAG TCC TGA GTA A CTA \\
\hline
\end{tabular}

Model 2000 (Freeze Dry Company International Incorporated, Nisswa, Minnesota, USA) was used for lyophilization of the Argentine samples. The specimens were kept in the individual microcentrifuge tubes and placed in the lyophilizer for approximately $24 \mathrm{~h}$. After the lyophilization protocol was finished, the larvae were shipped to the University of Nebraska-Lincoln (USA). Upon receipt, the specimens were stored in a Revco Legaci $-80^{\circ} \mathrm{C}$ freezer. The lyophilized samples arrived in microcentrifuge tubes and were maintained at room temperature.

DNA was extracted using a modification of Black and DuTeau's (1997) CTAB (hexadecyltrimethylammonium bromide) extraction protocol. Genomic FAW DNA was quantified using $1 \%$ agarose gel electrophoresis with a $22.2 \mathrm{ng} / \mu \mathrm{l} \mathrm{MW}$ Lambda DNA marker that run at $70 \mathrm{~V}$ for $20 \mathrm{~min}$. The agarose gel contained $30 \mu \mathrm{l}$ of ethidium bromide $/ 250 \mathrm{ml}$ agarose gel to fluoresce the bands. The agarose gels were analysed using an ultraviolet photo box and Genomic Solutions Software (Ann Arbor, Michigan, USA) to visualize the DNA bands. Genomic DNA was diluted with

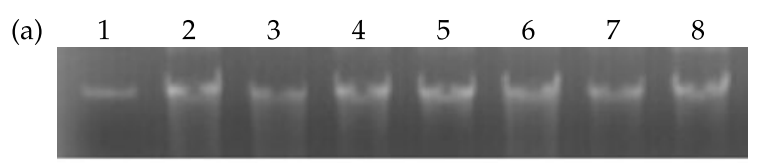

(b)
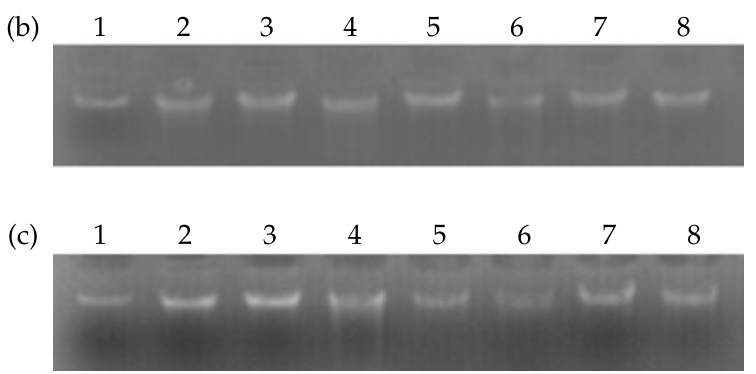

Fig. 1. (a) DNA quantification of Argentine (lyophilized) samples; lane 1 is lambda DNA $(22.2 \mathrm{ng} / \mu \mathrm{l})$, lanes $2-8$ are the quantified DNA from seven Argentine samples. (b) DNA quantification of Iowa (fresh) samples; lane 1 is lambda DNA $(22.2 \mathrm{ng} / \mu \mathrm{l})$, lanes $2-8$ are the quantified DNA from seven fresh Iowa samples. (c) DNA quantification of Mexican (ETOH) samples; lane 1 is lambda DNA $(22.2 \mathrm{ng} / \mu \mathrm{l})$, lanes $2-8$ are the quantified DNA from seven Mexican samples. 


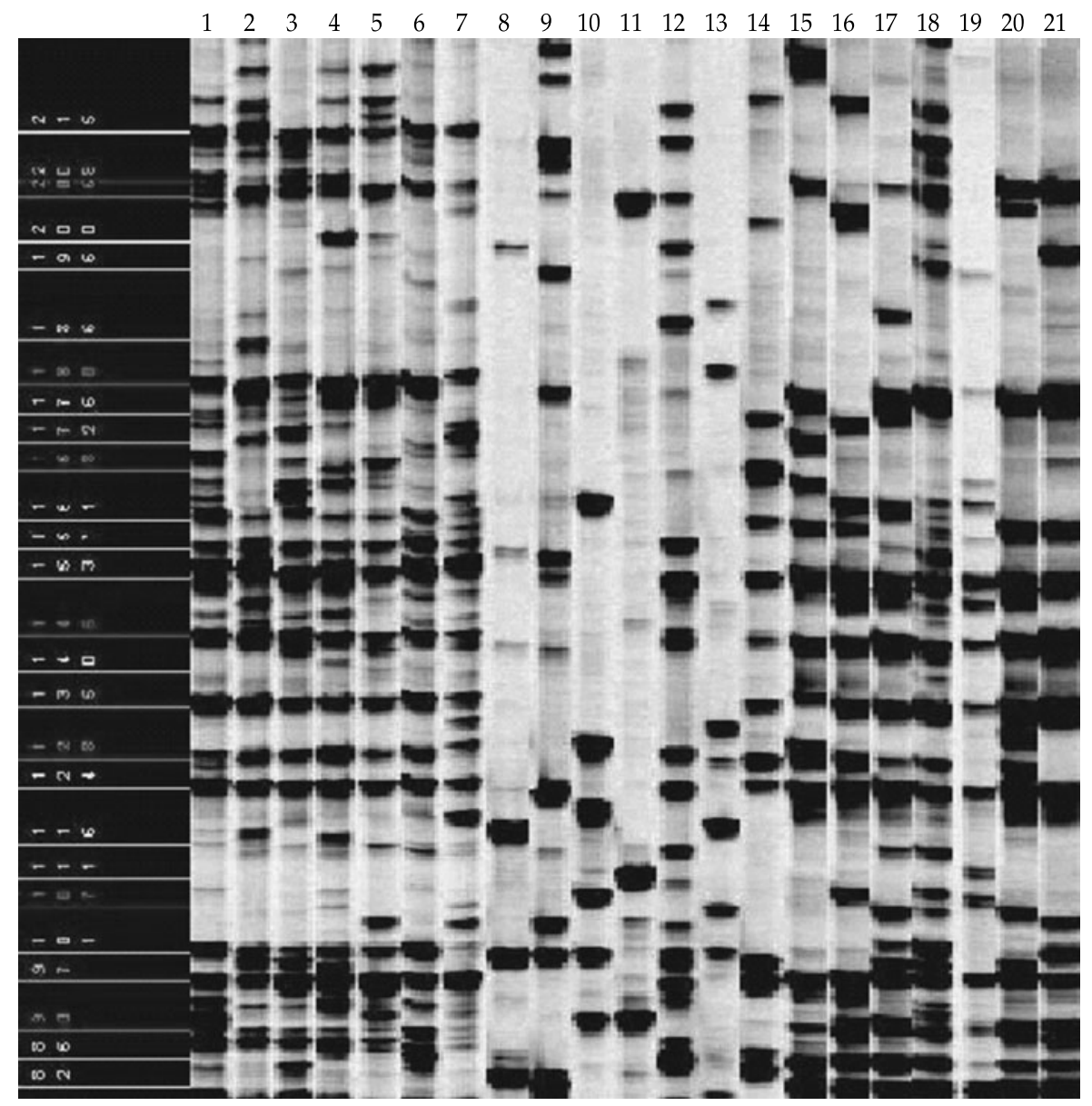

Fig. 2. Amplified fragment length polymorphism polyacrylamide gel electrophoresis (PAGE) using E-ACT (labelled) and M-CAC (unlabelled) primers ${ }^{+}$. Lanes 1-7 are lyophilized individuals from Argentina, lanes 8-14 are fresh individuals from Iowa and lanes 15-21 are individuals preserved in 95\% ETOH from Mexico. Numbers on the side are Bps. ${ }^{+}$PAGE bands have been compressed for visualization purposes using SAGA Generation 2 software (LI-COR, Lincoln, Nebraska, USA).

regions of DNA for analysis $(\mathrm{E}-\mathrm{ACT} \times \mathrm{M}-\mathrm{CAC}$, $\mathrm{E}-\mathrm{ACT} \times \mathrm{M}-\mathrm{CAG}$ and E-ACT $\times$ M-CTA; Table 2). Each primer was labelled with 700 dye (LI-COR, Lincoln, Nebraska, USA). Polyacrylamide gel electrophoresis (PAGE, 6.5\% polyacrylamide) was completed using a Gene Read IR 4200 sequencer (LI-COR). The PAGE gels were scored and analysed using SAGA Generation 2 software (LI-COR).

\section{Results and discussion}

One challenge of using lyophilized insects is that the specimen becomes very brittle from the lyophilization process; this causes problems in removing the gut from the muscles, because using a scalpel to scrape the gut off the muscle may cause the tissue to break. To alleviate the problem of removing the gut from the lyophilized FAW larvae, another component to the DNA extraction protocol was added. Prior to DNA extraction, the insect specimens were washed with double-distilled autoclaved water and then soaked in a doubledistilled water bath for $10 \mathrm{~min}$. The water bath larval soak rehydrates the FAW larva and softens the tissue. After the larva is softened, an incision is made and the gut contents are successfully scraped out. Then the DNA was extracted with $100 \%$ success.

All of the bands visualized by $1 \%$ agarose gel electrophoresis indicated good genomic DNA (Fig. 1a-c). FAW larvae yielded large amounts $(50-150 \mathrm{ng} / \mu \mathrm{l})$ of DNA; only $7 \mu \mathrm{l}$ of genomic DNA were used per sample for AFLP. The genomic DNA was diluted and quantified to $22.2 \mathrm{ng} / \mu \mathrm{l}$ for each sample. After quantification, each DNA sample was used in AFLP using three primer combinations (Figs 2-4) to verify that the lyophilization procedure preserves DNA suitable for molecular genetic comparisons. The AFLP PAGE of different samples showed intra- and inter-sample differences 


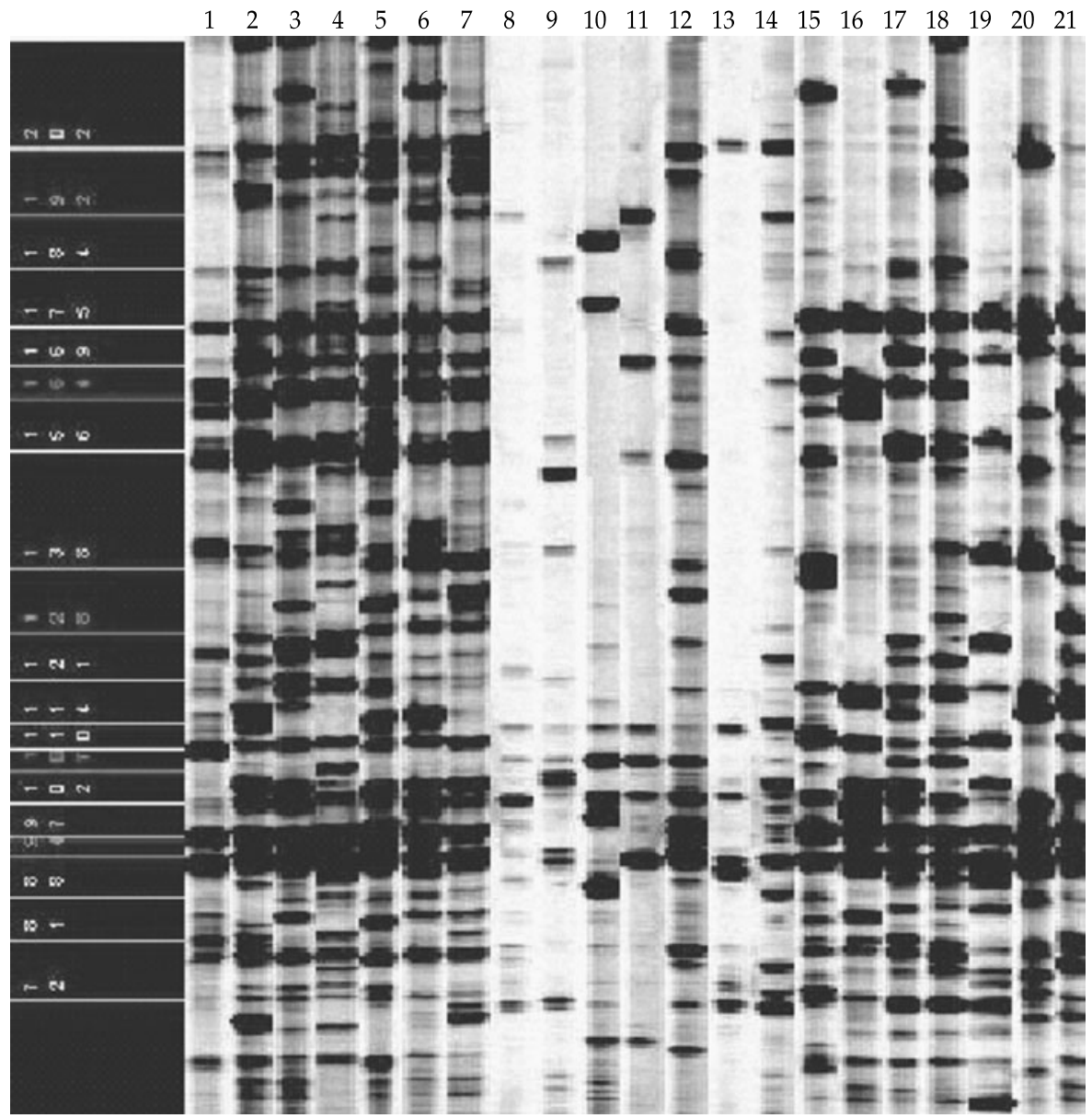

Fig. 3. Amplified fragment length polymorphism polyacrylamide gel electrophoresis (PAGE) using E-ACT (labelled) and M-CAG (unlabelled) primers ${ }^{+}$. Lanes 1-7 are lyophilized individuals from Argentina, lanes 8-14 are fresh individuals from Iowa and lanes 15-21 are individuals preserved in 95\% ETOH from Mexico. Numbers on the side are Bps. ${ }^{+}$PAGE bands have been compressed for visualization purposes using SAGA Generation 2 software (LI-COR, Lincoln, Nebraska, USA).

of the S. frugiperda populations, and they were discernible by region showing similar polymorphisms to the fresh samples.

The increase in international collaborations in agricultural research and the multiple molecular tools available has made it important for scientists to be able to attain high-quality genomic and mitochondrial DNA. Lyophilized insect material does not have to be frozen and can be stored dry at room temperature. Our results corroborate that lyophilized material offers advantages in terms of storage and quality of DNA isolated from microbes such as fungi (Punekar et al., 2003) or bacteria. Lyophilization works well for preserving insects for extracting genomic DNA for AFLP analysis.

The use of the freeze-drying procedure for taxonomic studies of mosquitoes was reported by Harbach and Harrison (1983), mentioning that despite limitations, freeze-drying is a satisfactory method of preparing specimens for morphological comparison. However, the authors did not report this method for molecular studies.

Using lyophilization, we increased our DNA extraction protocol by adding the rehydration step, but it only increased the total time for the extraction by approximately $15 \mathrm{~min}$. The most limiting factor for using lyophilization is to gain access to a lyophilizer. However, many research universities and agricultural chemical companies nowadays possess lyophilizers, which are mainly used for plant and bacterial research. Additionally with our method of lyophilization, we found that our samples could be stored at room temperature as well. These results provide a potentially valuable tool for international shipment of insect samples. Lyophilization of insect samples for molecular analysis is convenient for transportation to various sites for study. 


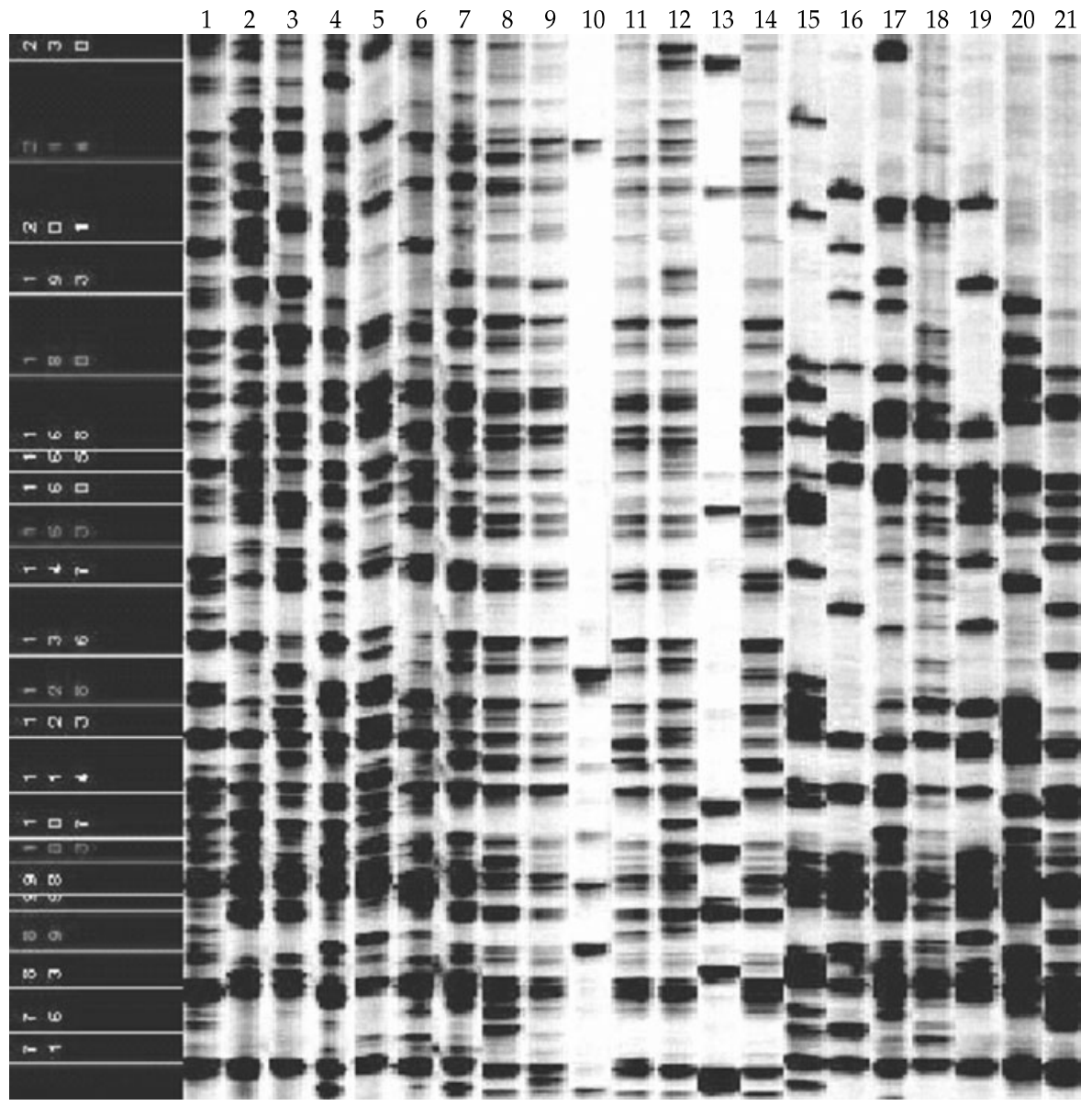

Fig. 4. Amplified fragment length polymorphism polyacrylamide gel electrophoresis (PAGE) using E-ACT (labelled) and M-CTA (unlabelled) primers ${ }^{+}$. Lanes 1-7 are lyophilized individuals from Argentina, lanes 8-14 are fresh individuals from Iowa and lanes 15-21 are individuals preserved in 95\% ETOH from Mexico. Numbers on the side are Bps. ${ }^{+}$PAGE bands have been compressed for visualization purposes using SAGA Generation 2 software (LI-COR, Lincoln, Nebraska, USA).

\section{Acknowledgements}

We thank Miguel Ángel Aguayo-López, Rector of the Universidad de Colima, and CONACYTMexico for a grant to Dr Jaime Molina-Ochoa. This paper is a contribution of the University of Nebraska-Lincoln, Agricultural Research Division, Lincoln NE 68583, the Monsanto Company, 800 North Lindbergh Boulevard, St Louis, Missouri 63167, the USDA-ARS-SPASRU Screwworm Research Unit, Panama City, Republic of Panamá, and the Universidad de Colima-Facultad de Ciencias Biológicas y Agropecuarias, Tecomán, Colima 28 930, México.

\section{References}

Black W. C. IV and DuTeau N. M. (1997) RAPD-PCR and SSCP analysis for insect population genetic studies, pp. 361-373. In The Molecular Biology of Insect Disease
Vectors: A Methods Manual (edited by J. M. Crampton, C. B. Beard and C. Louis). Chapman \& Hall, London. Busato G. R., Grützmacher A. D., de Oliveira A. C., Vieira E. A., Zimmer P. D., Kopp M. M., Bandeira J. D. M. and Magalhães T. R. (2004) Analysis of the molecular structure and diversity of Spodoptera frugiperda (J. E. Smith) (Lepidoptera: Noctuidae) populations associated to the corn and rice crops in Rio Grande do Sul State, Brazil. Neotropical Entomology 33, 709-716.

Fukatsu T. (1999) Acetone preservation: a practical technique for molecular analysis. Molecular Ecology 8, 1935-1945.

Harbach R. E. and Harrison B. A. (1983) Freeze-drying adult mosquitoes for taxonomic study. Mosquito Systematics 15, 50-54.

Hoy M. A. (2003) Insect Molecular Genetics - An Introduction to Principles and Applications, 2nd edn. Academic Press, San Diego, California.

Kang T.-J. and Yang M.-S. (2004) Rapid reliable extraction of genomic DNA from various wild-type and transgenic plants. BMC Biotechnology 4, 21-28. 
McMichael M. and Prowell D. P. (1999) Differences in amplified fragment-length polymorphisms in fall armyworm (Lepidoptera: Noctuidae) host strains. Annals of the Entomological Society of America 92, 175-181.

Punekar N. S., Sureshkumar S. V., Jayashri T. N. and Anuradha R. (2003) Isolation of genomic DNA from acetone-dried Aspergillus mycelia. Fungal Genetics Newsletter 50, 15-16.
Saha S., Callahan F. E., Dollar D. A. and Creech J. B. (1997) Cotton improvement: effect of lyophilization of cotton tissue on quality of extractable DNA, RNA, and protein. Journal of Cotton Science 1, 10-14.

Vos P., Hogers R., Bleeker M., Reijans M., van de Lee T., Hornes M., Frijters A., Pot J., Peleman J., Kuiper M. and Zabeau M. (1995) AFLP: a new technique for DNA fingerprinting. Nucleic Acids Research 23, 4407-4414. 